\title{
THE PROGRAM OF CRIME PREVENTION AND SOCIAL PATHOLOGY IN THE CZECH REPUBLIC - CHOSEN HISTORICAL ASPECTS
}

\author{
Miroslav Pilát
}

\begin{abstract}
The article describes the basis, the theoretical framework of criminality prevention in the Czech Republic until the year 2015, the structure of criminality prevention in the Czech Republic, the levels of prevention activities, the history of Criminality prevention and social pathology program in the Czech republic, the strategy of criminality prevention in the Czech republic, the organization of criminality prevention programs in the Czech Republic, the phases of criminality prevention creation on the local level.
\end{abstract}

\section{Keywords}

Crime prevention, social prevention, situation prevention, preventive policy, prevention strategy objects of crime prevention.

\section{Preface}

At the end of the last century, the Czech Republic, in accordance with good practice criminological advanced democracies, pushed the idea that increasing crime can not in any case face a mere increase in repressive means. It was recognized that the mere threat of stricter criminal repression (or direct application of criminal sanctions), or related augmentation of numbers in the police, the number of prosecutors or judges or prison capacity expansion, never led to the removal and even often do not reduce crime. In addition, the highly repressive means a very challenging economic and burden the state budget (Večerka, 2001). Večerka (2001) have their work wonders why repression alone does not meet the expected purpose?

According to the author, to which we incline, it is mainly because the personal characteristics of the conscious criminally prepared and committed people are in an overwhelming number of cases such that it will not allow the idea that they could be in 
the commission of the offense detected, located and subsequently affected. Repression is these people perceived as "other problem". And even if you have personal experience with the criminal sanction. His identification and punishment of delinquency tend to interpret as punishment for the former awkwardness or small preparedness (which is no longer in the future will not repeat), as coincidence fatally adverse done deeds or betrayal accomplices. The actual sentence, however, is not what it could be and certainly enough to deter them from future criminal behavior. Calling the general public for increased criminal repression as the only effective means of countering crime is therefore naive. In accordance with Večerka (2001) can therefore be concluded that well-managed preventive work is an effective means of reducing crime and other undesirable phenomena in society. Prevention is not only a natural regulator of antisociality and asociality, but also an important factor in the development of a society based on law, justice and respect for others.

\section{Background and Theoretical Framework for Crime Prevention in The Czech Republic}

Crime Prevention Department of the Ministry of Interior of the Czech Republic (Crime Prevention, 2008) in accordance with the theory and practice defines the basic concepts in the field of crime prevention in the following manner.

Preventive policy is a proactive crime control strategy, which relies primarily on non-punitive means. It deals with the elimination of social pathologies, and reducing the motive and opportunity to commit crimes. Range of entities preventive policy includes among agencies involved in criminal proceedings - justice system, the police, prosecutors, courts and prison system (which of course does not play a major role), and other institutions - such as non-punitive public authorities, public interest associations, churches, businesses and individual citizens. Crime prevention is the next part of the criminal policy of repression.

Crime prevention involves a set of repressive measures, i.e. all activities by state, public and private entities seeking to prevent the commission of crime and reducing the fear of it. These include measures aimed at or resulting in a reduction of the extent and severity of the crime and its consequences, whether through reducing criminogenic opportunities, or by potential offenders and victims of crime. It is a measure of social prevention, situational prevention, including public about how to protect against crime and assist victims of crime. Crime prevention is closely linked to the prevention of other social phenomena, the most serious of which include various forms of addiction. In the literature we can find different notion of prevention.

One of the most comprehensive definitions considers the definition Vlček and Zapletal (in Večerka, 1997, p. 6), according to which crime prevention "...includes all activities aimed at preventing crime, to reduce the incidence way to prevent the perpetration or 
neutralization of causes and conditions of crime offenses (criminogenic factors). These include measures aimed at or resulting in a reduction of the extent and severity of the crime. Whether through reducing criminogenic opportunities, or by potential offenders and victims of crim. Prevention therefore represents an attempt to eliminate criminal activity before the start of or prior to the proceeding."

Criminogenic factors (social environment, the causes and conditions of crime), potential or actual perpetrators of crime and potential or actual victims of crimes are treated as objects of crime prevention.

Crime prevention includes all measures to reduce the risk of crime and their harmful consequences to individuals and society, including the fear of crime. Crime prevention tries to influence diverse causes of crime. Law enforcement and criminal sanctions in this context be left aside, despite their potential preventive effects ${ }^{1}$ (Prevention Strategy, 2011).

\section{The general goal of crime prevention}

The overall aim of the preventive work in the area of crime is "maintaining the behavior of members of society in a majority of citizens consensually agreed standards and values, using funds primarily of non-penalty nature. Prevention is therefore deliberately seeked to avoid major distortions of the most important social regulative. These include the first rules of substantive criminal law, which are (or should be) an extract of low morals of society. These standards, of course, does not exhaust all the citizens in the area of standards and values of formal and informal means of protecting against disruption" (Havrdová, 2007, p. 84).

Crime prevention, however, can not be fully assessed in isolation, but must be understood in the broader context of prevention of risky behavior.

"The term risky behavior while we mean behavior, which results in a demonstrable increase in health, social, educational and other risks for the individual or society." (Miovský, 2010, p. 23)

Among others (bullying, violence in schools, substance abuse, racism, truancy, etc.) into the patterns of risk behavior ranks as general criminal conduct (Miovský, 2010).

Unlike traditional criminal repression, which is implemented formal crime control institutions (police, prosecutors, courts) already represents a response to the offense and the offender through the criminal process and the consequent imposition of criminal sanctions. Crime prevention in the broadest sense can be understood as interventions implemented by different actors at different stages, the main purpose is basically to prevent crime before it occurs. In essence it concerns to prevent crime (Štefunková, 2012).

\footnotetext{
$12^{\text {th }}$ United Nations Congress on Crime Prevention and Criminal Justice. Salvador, Brazil, 12-19 April 2010.
} 


\section{The Structure of Crime Prevention in The Czech Republic}

In the literature, mainly in Czech Republic assert tripartite division crime prevention:

a) in terms of content on social prevention,

b) in terms of opportunities for situational prevention,

c) in terms of sacrifice for victimological prevention, or prevention of how not to become a victim of a criminal offense.

a) Social prevention is an activity affecting the process of socialization and social integration, and activities aimed at changing negative social and economic conditions that are considered key causes of crime. Social prevention is part of social policy. The effectiveness of social prevention is difficult to statistically or economically measurable; it can be only inferred, in terms of estimates of the social perspectives of individuals Objects preventive action (Crime Prevention, 2008).

b) Situation Prevention builds on the experience that certain types of crime occur at certain times at certain locations and under certain circumstances. Through action regime, physical and technical protection seeks to minimize the criminogenic conditions. Operates most effectively in reducing property crime. The success of situational prevention is high, but it is conditioned by adequate choice of measures and financial and personnel resources invested in it. The focus of responsibility for situational prevention measures rests with citizens and communities and within the defined competencies of the Ministry of the Interior, or the Czech Police (Crime Prevention, 2008).

c) Victimization prevention and assistance to victims of crime is based on the concepts of safe behavior differentiated with respect to various criminal situations and mental readiness at risk. In practice, it is a group and individual medical, psychological and legal counseling, training in self-defense strategies and promotion of technical means of protection against crime. It uses methods of social and situational prevention, according to the degree of danger to the primary, secondary and tertiary levels (Crime Prevention, 2008).

The above concept of prevention to be broken down in terms of the main addressees of the tripartite further divided into:

1. Primary prevention,

2. Prevention of secondary,

3. Tertiary prevention.

This breakdown allows the combination of both criteria, such as social or situational prevention is tracted mostly as primary, secondary or tertiary.

In contrast, Schneider (in Večerka, 1997), based on the work Lejins (1967) distinguishes three main categories of crime prevention:

a) Prevent lawful, i.e. based on the criminal law or closely related,

b) Prevention intervention, which has similarities with the concept of prevention of social, 
c) Preventing mechanical, which has many of the same characteristics with situational prevention, as in the Czech Republic used in the literature.

\subsection{Levels of prevention activities}

As mentioned above, social and situational approaches are complementary in primary, secondary and tertiary prevention.

1) Primary prevention is in our conditions is seen as a strategy of indirect and involves primarily educational, educational, recreational, educational and consulting activities focused on the general public. Particular attention is focused on the positive influence especially children and youth (leisure time, sports facilities). The focus of primary prevention lies in families, in schools and in local communities.

2) Secondary prevention is seen as a direct strategy focused on risk individuals a group of persons who have an increased likelihood of becoming offenders or victims of crime (specialized social care), socially pathological phenomena (such as drug and alcohol abuse, truancy, gambling, loafing, vandalism, and interethnic conflicts, long term unemployment) and causes of criminogenic situation. It also aims to protect the material value, which are often the object of interest offenders.

3) Tertiary prevention is designed as a direct strategy, which consists in resocialization criminally disturbed persons (jobs, retraining, social and family counseling, assistance in obtaining housing ...). Its aim is to maintain the results of previous interventions and reconstruction of dysfunctional social environment (Crime Prevention, 2008).

Responsibility for the primary prevention of Social and falls within the scope of family, community and the Ministry of Education, Youth and Sports. Secondary and tertiary prevention with regard to the technical demands of the individual activities of affairs of the Ministry of Labour and Social Affairs and in some contexts and the Ministry of Justice and Ministry of Health. In the specific part of the population has the Ministry of Defence (Crime Prevention, 2008).

\section{Victimological crime prevention}

A special kind of preventive activities (which began to develop in the context of the concepts of situational prevention) are by Štefunková (2012) projects aimed at protecting potential victims of crime (the so-called Victimological prevention; victima word - Latin, victim - English = sacrifice). Victimological prevention combines elements of social and situational crime prevention. Its purpose is to prevent crime with the active participation of potential victims. States that this type of prevention is also done in three basic steps. 


\section{History of The Program of Crime Prevention in The Czech Republic}

\subsection{The first steps in the field of crime prevention in the Czech Republic}

Since the early eighties in democratic countries preventive policy in effect become equal part of criminal policy, which has since been trying in access to crime to achieve a balance between prevention and repression. Preventing crime in the Czech Republic, as systematically and systemically conceived action at the government level, became operational after 1993.

At the end of the era of the socialist state, although the importance of prevention of crime verbally acknowledged, but its concept and execution were very formal, prevention existed more on paper than in practice and this formal approach to prevention rather led to the discrediting of the notion of prevention at all than to practical effects. After 1990, concurrently with the profound social changes, there was a significant expansion of the crime. From 1989 to 1993, increased the number of recorded offenses more than tripled. In the same period, but the number of crimes increased by only $35 \%$ and the number of perpetrators by $50 \%$. There are forms of crime previously little known or less widespread, such as crime associated with drugs, symptoms of organized crime, crimes in the economic sphere, etc. The media began to invest crime substantially more attention than before. These phenomena, together with other influences considerably impressed with the social consciousness, which increased public concern over crime and heighten the sense of danger crime (Havrdová, 2007).

Due to an increase in fear of crime have been sharpening repressive attitudes of the public, calls for stricter penalties for offenders. Along with this, but especially the professional community began to deeply explore the possibilities and limits of criminal repression and the need to draw up a comprehensive criminal policy, focusing on the causes of crime and its influencing or stimulating factors. Gradually the rehabilitation of the discredited concept of prevention, understanding of the need for preventive policies and to search for new content and organization of preventive work. In 1991, Czechoslovak Helsinki Committee opinion on the issues of crime and potential expansion of criminal legislation this expansion face. In an opinion entitled "The right of citizens to safety in the rule of law" 2 has requested that in all three governments (federal, Czech and Slovak), that committees of crime prevention as their inter-departmental bodies. It also landed requested that such committees were also in the assemblies of the city's most vulnerable crime and that these committees prepare the necessary preventive programs. In this opinion, outlined a number of measures that such programs should take into account (Havrdová, 2007).

2 Posted in Literary papers of 8 January 1991 Lawyer magazine 1/1992, 83-86. 
The above opinion had played a significant role in discussions about the need for preventive policies and organization of preventive action, and so in 1993 the Government of the Czech Republic in its Resolution No. 22/1993 to handle social program and crime prevention. The foundation stone of the construction of the institutional conditions for the development of preventive policies in the Czech Republic was laid in 1993, when the Government Decree No. 617/1993 established the Ministry of the Interior of the Czech Republic Committee for Crime Prevention, whose composition a representation of the different ministries and institutions are presented in the following chapter.

National Committee for the Prevention of Crime was established with the task of coordinating the activities of the relevant central bodies of state administration in the field of crime prevention, collaborate with non-public sector (civil initiatives and movements, churches and other organizations), methodically lead and support the development of preventive activities and the activities of local authorities for crime prevention, to support the implementation of preventive programs and projects and evaluate their effectiveness, prepare and submit to the government policy documents relating to the prevention (Osmančík \& Novotný, in Havrdová, 2007).

The central idea of the establishment of this committee, which became the basis for building a prevention system in the Czech Republic, was that his role is not to prevent drive, but rather to coordinate and initiate and support. The focus of prevention from the outset was directed to the activities of the local authority and local governments, depending on specific local conditions, problems and needs. The establishment of the National Committee for the Prevention of Crime therefore did not only mean systemic solutions to prevent crime at the level of central government authority and the emergence of authority for the preparation of preventive policies but also heralded the basic orientation of this policy, emphasizing the key role and responsibility of local authorities for developing and implementing their own preventive policy.

At the same time, in January of the same year established the Department public relations and prevention of the Ministry of the Interior and exactly after three years of his tenure, the department was abolished and its powers took over part of the newly established Department of Prevention, at 1 October 1996, the department was renamed the Department of Crime Prevention and the Department bears the name today.

In the same year, the prevention of crime in the Czech Republic for the first time from the state budget funds earmarked a major pillar of preventive activities became a crime prevention program at the local level, which was implemented with the assistance of local self- government special-purpose grants. These financial grants allocated on the basis of the submitted projects, the National Committee for the Prevention of Crime.

The main characteristic of the period 1996-2007 was building a system of crime prevention including organizational, personnel, information and financial security. The generated system is based on preventive programs ministries represented in the Committee of crime prevention, crime prevention programs at the local level, the research, analysis, evaluation and prevention activities of the Ministry of Interior and the Police of the Czech Republic on cooperation with non-governmental organizations and entities that operate in situational prevention. 


\subsection{Crime Prevention Strategy in the Czech Republic from 1996 to 2007}

The first crime prevention strategy was prepared by the Ministry of the Interior in 1996, originally as a four-year strategic document. Until now, the Czech government approved the implementation of several other strategies that gradually encompass a range of measures, activities and approaches in the field of crime prevention. Especially in the period from 1996 to 2004, formed the other areas and bodies of crime prevention are closely related (e.g. caused by the Probation and Mediation Service, adopting new laws related with the prevention of crime).

An important step to stabilize the financial security has been made by the Government Resolution No. 137 of 1996, which were both released funds from the state budget for the implementation of this program in 1996, and at the same time, this amount was divided into chapters budgetary sector represented in the Committee for the Prevention of Crime. At the same time the Minister of Interior and Chairman of the National Committee for the Prevention of Crime deposited submit a draft of association and spending of funds from the state budget for social prevention programs, crime prevention and drug addiction (Gjuričová, in Havrdová, 2007).

In this way, in the mid-nineties of the last century in the Czech Republic built in phases and subsequently stabilized system of preventive work.

He was appointed the National Committee for the Prevention of Crime as coordination, conceptual and methodological body of the Government of the Czech Republic and system support prevention activities from the state budget. They were first developed departmental crime prevention programs and in particular it was decided to focus on the basic focus of preventive work at the local level, ie in cities and municipalities, and the responsibility and accountability of local public authorities.

These abovementioned basic principles of prevention in the Czech Republic were incorporated into the Crime Prevention Strategy in 2000, which was a fundamental conceptual document crime prevention approved by the Czech Government Resolution No. 209 of 9 April 1997. At this first ever Crime Prevention Strategy then followed her other updates on the fulfillment of which the government is informed in its annual reports in which they are currently defined which tasks in the field of crime prevention for the future (Havrdová, 2007).

\subsection{Strategy for Crime Prevention 2008-2011}

Crime Prevention Strategy for the years 2008-2011 (the "Strategy"), which was approved by the Czech government in 2007 , builds on the previous strategy and aims to continue to increase the perception of safety and to reduce the rate and severity of the crime. The strategy was based on the latest findings of scientific research and home and foreign experience. In addition to the above content preventive activities, the Strategy 
emphasizes the need to build implementation capacity, this means strengthening the prevention of crime, including the conditions for the implementation of national, regional and local prevention strategies and ensure their financial and personnel support (Štefunková, 2012).

As part of the Crime Prevention Strategy for 2008 to 2011 there was a change in the organizational scheme of crime prevention in the Czech Republic, which was divided into three levels - the republican county and city. By creating a regional level to enhance the coordination and methodological role of regions to municipalities falling under the jurisdiction of counties. Municipal level accounted for a large city (over 25,000 inhabitants), which had an opportunity, subject to conditions, to draw funds from the state budget for crime prevention for the duration of the Strategy. The condition for inclusion in the regional and municipal levels of crime prevention was to process safety analysis, which may have been formulated in regional and urban crime prevention, which are subject to approval by regional council or village.

\subsubsection{Improving the interdepartmental system of care for vulnerable and at-risk children}

A key project to criminally risky and vulnerable children and young people in this period Early Intervention System (hereinafter referred to as "EIS"), which has long been developed by the Ministry of the Interior (author and administer the projects), the Ministry of Justice (Probation and Mediation Service) and the Ministry of Labour and Social Affairs. The project ${ }^{3}$ is aimed at improving cooperation institutions in whose jurisdiction the care of vulnerable children in the earliest stages of socio-pathological child development, crime, as well as cases of abuse, neglect and child abuse. The aim is to exchange information about problem child in the position of perpetrators, witnesses or victims of crime, rapid correction of unsatisfactory condition (measures) and targeted and specific preventive measures. Between 2008 and 2009 the MLSA to the Government three materials related to the transformation of the system of care for vulnerable children. The first was the "Analysis of the current state of institutional provision of care for vulnerable children" (Government No. 293/2008), which charted the situation in the system of care for children at risk in terms of the inclusion of this agenda under different ministries. The second "Proposed measures to transform and unify the system of care for vulnerable children - basic principles" (Government Resolution No. 16/2009), which define the basic assumptions and principles on which the transformation process based. The final then the "National Action Plan to transform and unify the system of care for

\footnotetext{
3 The project was the Crime Prevention Department in 1998 as a response to serious problems and deficiencies in the system of care for high-risk and vulnerable children. From 2000 to 2006 he was a pilot basis at two selected cities in the Czech Republic (Ostrava, Svitavy) (Prevention Strategy, 2011).
} 
children at risk for the period 2009-2011" (approved by Government Resolution No. $883 / 2009)^{4}$.

The transformation process continues to contribute significantly inter-ministerial coordination group to transform the system of care children ${ }^{5}$ at risk. In terms of legislation to strengthen the protection of children's rights in their maintenance, increased the rate of child protection from arbitrary interference in their private and family life and the new Penal Code has strengthened the criminal standard of protection of children against abuse, exploitation, neglect and child trafficking (Prevention Strategy, 2011).

\subsection{Crime Prevention Strategy in the Czech Republic for 2012-2015}

Another important step in the prevention of crime in the Czech Republic was the development and adoption of a strategic document entitled Crime Prevention Strategy in the Czech Republic for 2012-2015, approved by the Czech Government Resolution No. 925 of 30 November, 2011. The present document benefited from the conclusions and results of previous crime prevention strategies, from the practical experience gained, international knowledge and research in the field of crime prevention. It builds on coordinated system collaboration between institutions and stakeholders at all levels of government and civic life. We comply with international recommendations and in accordance with proven knowledge and experience at the national level, it governs ${ }^{6}$ (Prevention Strategy, 2011).

\footnotetext{
${ }^{4}$ Its aims are: preference childcare in the family to institutional care and thus reduce the number of children in institutions; deepening preventive work with vulnerable families and reduce the number of children withdrawn from parental care, individual approach and multidisciplinary work and active involvement of children and their families in solving their own situation, personnel and financial strengthening of social-legal protection of children within local authorities, who will play a key role in coordinating the cooperation of all authorities providing assistance to vulnerable families; alignment of legislative changes, methodological materials and practices within the scope of all departments involved in the care of vulnerable children (Home Office, 2011).

${ }^{5}$ Member of the Ministry of Labour and Social Affairs, Ministry of Education, Youth and Sports, Ministry of Health, Ministry of Justice, Ministry of Interior, Ministry of Regional Development and the Minister (Agent) Human Rights (Prevention Strategy, 2011).

6 The Czech government in shaping and implementing the policy of crime prevention in the long term respects international recommendations, especially from the United Nations. Experience gained with the implementation of crime prevention initiatives since 1996, largely supported and recommendations of the United Nations crime prevention and criminal justice, which is one of the important agendas of the UN.

The strategy formulates the following basis for its implementation, which are in accordance with established Conclusion 12 UN Congress on Crime Prevention and Criminal Justice (Salvador, April 2010) and correspond to the experience and knowledge of the current implementation of crime prevention in the Czech Republic:

(a) The head of state's role at all levels in order to create and maintain the institutional framework of crime prevention;

(b) Integration of crime prevention strategies among socio-economic development;

(c) Cooperation between government, civil society and the business sector;

(d) Sustainability and responsibility, it is appropriate long-term financing, production, maintenance and evaluation of programs and total transparency of the use of resources;

(e) Procedure based on knowledge, as a basis for any crime prevention strategy used multidisciplinary body of knowledge about the problems of crime, its causes and best practice;

(f) Respect for human rights and the rule of law and promoting a culture of legality;

(g) The attention paid to the links between local crime and transnational organized crime;

(h) Differentiation strategies for specific groups, especially for boys and girls, men and women and vulnerable members of society (Prevention Strategy, 2011).
} 
In this material, the government claimed the above definition of crime prevention and the basic principles of crime prevention that have been defined and adopted at the $12^{\text {th }}$ United Nations Congress on Crime Prevention and Criminal Justice (Salvador, Brazil, April 12 to 19,2010 ) and established the vision, strategic goals and priorities in the field of crime prevention.

\subsection{International cooperation in crime prevention}

International activities of the Czech Republic in the field of crime prevention will focus on cooperation within the European Union. Ministry of the Interior represents the Czech Republic in the European Crime Prevention Network (European Crime Prevention Network, EUCPN) established by the Council Decision 2009/902/JHA. This network provides the tasks of member countries through multi-year strategy to strengthen the role of crime prevention and more effective prevention activities throughout the European Union. One of the successful activities is the annual award of prizes for the best European preventive project (European Crime Prevention Award, ECPA), which allows for the sharing and exchange of good practice in crime prevention within the EU. Similar competitions are taking place in Canada, USA, Australia or the United Nations announced it. The Ministry of Interior will be in accordance with the rules ECPA annually nominate one project on the topic and the need for an objective nomination will fund an annual national two-round selection (Prevention Strategy, 2011).

Strategic priorities in the field of crime prevention are addressed in the framework of the United Nations (UN Office on Drugs and Crime - UNODC, the Committee on the Elimination of Racial Discrimination - CERD, Committee on the Elimination of Discrimination against Women - CEDAW, the UN Commission on Crime Prevention and Criminal Justice - CCPCJ. Czech Republic is represented in these institutions and regularly informed of specific activities in the field of improving safety and compliance with applicable international conventions. An important partner of the Czech Republic in the field of international cooperation at the level of NSAs European Forum for Urban Safety $^{7}$ (The European Forum for Urban Safety) (Prevention Strategy, 2011).

\footnotetext{
7 EFUS is a European non-profit organization that was established in 1987 as platform mayors of European cities. It aims to build a network of European local authorities, to exchange information and practical experience in reducing crime and promoting the role of local government in the national and European politics. Today, it has approximately 300 local governments and its main focus is the issue of security in cities. The Czech Republic is a member of EFUS city of Brno (Prevention Strategy, 2011).
} 


\section{The Organization of Crime Prevention Programs in The Czech Republic}

\subsection{The level of organization of crime prevention in the Czech Republic}

In the Czech Republic, the prevention of crime organized on three levels:

1. The inter-ministerial level - the focus of inter-agency cooperation is the creation of a preventive policy of the Government in relation to traditional (general) crime prevention and coordination of the activities of individual departments represented in the Committee on Crime Prevention and encouraging new activities.

2. At the departmental level - crime prevention programs are based on the substantive scope of the various ministries, enrich their daily activities with new elements and approaches and affect the formation of the relevant legislation.

3. At the local level, involving public authorities, police, NGOs and other institutions operating in the villages. The essence of crime prevention at the local level is the optimal distribution of powers in the areas of social and situational prevention with regard to the local situation, needs and possibilities (Crime Prevention, 2008).

In terms of efficiency are the most effective crime prevention programs at the local level. They represent a system of methodological, conceptual and financial support from the central state and local governments and support of crime prevention programs in cities and towns loaded high rates of crime and other crime-risk events. The essence of these programs is the cooperation of the state government, local government, police and NGOs. Shot of the program is conditional upon the local situation in the development of socio-pathological phenomena, needs, interests and abilities of people and resources. For the implementation of crime prevention programs are the responsibility of the municipal council (Crime Prevention, 2008).

Crime Prevention Department of the Ministry of Interior acts as a central authority in the field of internal order and security in the development and implementation of the concept of crime prevention. At the same time acts as the Secretariat of the National Committee for the Prevention of Crime. National Committee for the Prevention of Crime is to co-initiating, coordinating and methodical body set up by the Ministry of the Interior of the Government Resolution dated 3 November 1993 No. 617 It is governed by statute Rules and regulations approved by the Government of the Czech Republic. Usually meets at one month and follows the plan of action. The activities of the National Committee is designing preventive policy of the Czech Government Inter-ministerial level and its instantiation at the local level and is responsible for the processing of materials for the Government of the Czech Republic in the field of crime prevention and approve applications for grants for crime prevention projects submitted by cities, including the funds earmarked in the state budget chapter Ministry of the Interior. National Committee has eighteen members, the chairman 
of the National Committee is the Minister of the Interior and Executive Vice is one Deputy Minister of the Interior.

Other members include representatives from:

- Ministry of Finance of the Czech Republic,

- Ministry of Defence of the Czech Republic,

- Ministry of Labour and Social Affairs of the Czech Republic - Department of Family Policy,

- Ministry of Labour and Social Affairs of the Czech Republic - Department of Social Services,

- Ministry of Justice of the Czech Republic,

- Ministry of Education, Youth and Sports of the Czech Republic,

- Ministry of Interior of the Czech Republic,

- Ministry of Health of the Czech Republic,

- Supreme Prosecutor's Office of the Czech Republic,

- General Directorate of the Prison Service of the Czech Republic,

- Institute for Criminology and Social Prevention,

- Police Presidium of the Czech Republic,

- Probation and Mediation Service of the Czech Republic,

- Czech Republic Government Council for Roma Community Affairs,

- Government Council for Drug Policy Coordination,

- Union of Judges Czech Republic.

This committee establishes the Commission for the selection of projects for urban crime prevention program, which is an advisory body of the National Committee for the granting of subsidies from the state budget. As a result of interdepartmental cooperation is an established system of crime prevention in the Czech Republic, which is based on the departmental prevention programs, crime prevention programs at the local level, the activities of the Police of the Czech Republic, NGOs and businesses.

The prevention of crime in the Czech Republic modified three levels which reflect the involvement of senior local government units (counties) in the system:

1. on national and departmental - coordinating role is played by an interdepartmental body of the National Committee,

2. Regional - Regional Offices,

3. Local - governments of cities and municipalities burdened by high levels of criminal risk phenomena.

\subsection{Organization of crime prevention in the Czech Republic at the local level}

Preventing crime at the local level, as was in the previous chapter, opinionated, is the basis of crime prevention in the Czech Republic. The preparation and practical implementation of preventive work are the responsibility of the municipal council, with an emphasis on collaboration and cooperation of all stakeholders involved in prevention activities, including 
a significant involvement of non-governmental organizations which have, in the area of crime prevention at the local level irreplaceable function.

Synergies at the local level in our terms and conditions expressed in particular in the so-called Complex in cooperative programs to prevent crime and social pathology at the level of cities, which gradually involved in prevention activities. These prevention programs were implemented since 1996 in cities of over 10,000 inhabitants burdened by higher crime rates and other social risk phenomena, from the year 2001 were made under the name of crime prevention program at the local level. Such program has been implemented gradually in CR 95 cities with more than 10,000 inhabitants and in 2003 was created the program in 24 other towns and villages. Under these programs were as in 2003 , financially supported by the 3,188 sub-projects with a total amount of over 550 million CZK (Havrdová, 2007).

In order to engage in prevention activities supported by smaller towns and more use of the experience and the potential of the Police of the Czech Republic was established partnership program, which was based on analytical and proactive role of police, from the regional level to the district level (local) department, which was based on the experience and the assumptions made in the implementation of crime prevention programs at the local level. The program is based on a partnership of the Police of the Czech Republic with municipalities, regional authorities and other stakeholders in addressing crime in high-risk areas and the preparation and implementation of projects that aim to limit local criminogenic conditions and positively influence the perception of safety. The pilot implementation was approved in 2003 and since 2005 has been announced as the only program of crime prevention at the local level. In addition to prevention programs announced and implemented at the local level, ie at the municipal level, are part of the preventive work in the Czech Republic also some specific nationwide preventive programs aimed at the selection of specific problem areas (drug problems, child protection, prevention of human trafficking for sexual abuse, etc.) (Havrdová, 2007).

\subsection{Phase formation of crime prevention at the local level}

\subsubsection{First phase - create the institutional prerequisites for preventive work in location}

A prerequisite for the success of preventive work at the local level deemed Večerka (1997) a political decision of the municipal council to address issues of crime prevention and social pathology in its territory long-term plan. It should be borne in mind that activities related to preventive work modifying the lives of all citizens of the municipality and require their consent pronounced just resolution of their elected representatives, i.e. the municipal council. 


\section{Commission of Crime Prevention}

A very important element in the structure of preventive work at the level of the village is the creation of a commission of crime prevention, which should be an advisory body of the municipal council within the meaning of the Act No. 128/2000 Coll., the municipalities (local government), as amended, and the establishment of which should come from the initiative board or municipal council.

The task to form the commission should have been given according to Večerka (1997) to the employee of the municipal (city) office, which was chosen for this task, based on challenging the bankruptcy proceedings, and shall be the coordinator of preventive work at the local level (the coordinator) ${ }^{8}$.

The function of coordinator should be prestigious enough and therefore according to Večerka (1997) he or she should be placed at the level of head of department of the municipal office and are therefore the service line directly subordinate to the Office of the Secretary, as a personnel manager.

This requirement, as well as a requirement Crime Prevention Department of the Czech Republic in the early days of the crime prevention program that the coordinator reports directly to the mayor of the municipality is often not fulfilled in practice. Rather, it may be seen by the fact that in the best case, the worker subordinate to the Head of Department (mostly Social Affairs) of the Municipal Office, in smaller communities or communities of moderate size often this function is combined from different functions (coordinator of community planning of social services, drug coordinator etc.) However, it is without doubt that the coordinator (sometimes we encounter the concept of crime prevention manager) should be a person of high professional and organizational well-founded, his competence and basic characteristics will be discussed below.

It is important that the composition of the commission of crime prevention as an advisory body of the municipal council, responded to local specificities and needs based on local human resources. The Commission should not in any event be calculated on the basis of a uniform dysfunctional schema or structure of another municipality. On the contrary, it is very appropriate that its composition responded to local differences and to include representation of all possible intervening entities in the widest range (institutions of public administration, non-governmental organizations active in the field of crime prevention, charitable and religious institutions and associations, individuals who have a preventive including the work). Experience shows that it is desirable that the committee members were together in mutual state of superiority or inferiority, because the problems that can often arise stems from involuntary award acceptance challenges. It is important that committee members at their institutions, which represent the Commission, held an important position so that they have the competence to implement measures promised. A very important role is played by the Czech Police Komsi that the coordinator can ${ }^{8}$ Government Resolution No. 341 of 15 June 1994 "program of social and Crime Prevention - current status and
starting in 1996," advises municipal experimentally verified in practice, the coordinator of preventive activities. 
provide invaluable information on recorded crime in the area of such high quality that can be the basis of security analysis in the village (Večerka, 1997).

\section{Coordinator (manager) prevention activities}

As mentioned above, a key role in developing and implementing crime prevention programs at the local level plays coordinator (manager) prevention activities at the local level. Večerka (1997) points out that the main responsibilities of the coordinator include analytical and advisory activities, i.e. continuous analysis of the situation in the region and communication with the municipality and the municipal office.

The coordinator is essential to have access not only to basic police statistics, but also to all the important analytical materials of the socio-economic area. Another key task of the coordinator is to create and update reports about people (their formal and informal groups) who provide (or could provide) a kind of preventive assistance and individuals who support this need in various forms. Finally, the coordinator should have an overview of socially excluded localities or areas at risk of social exclusion. Irreplaceable role has also coordinator in the preparation, management and coordinating the commission of crime prevention in the village. Another important role is played by the coordinator at popularization and dissemination activities, whose task is to create a favorable climate for prevention in the locality.

The above described activity suggests that the coordinator must be a person with good judgment, ability to communicate with people who are strongly motivated to do the job and able to work at different levels of the social structure and overcome difficulties associated with this. The coordinator should not only be a social worker, but also the manager. According to the research, implemented Večerka (2007) among social workers should be ideal coordinator man or woman aged $30-40$ years with secondary or university education, with a length of 3-5 years experience in a related field, residing in a place where will perform their work as at least partial knowledge of a foreign language. Conversely irrelevant according to the results of research for performance coordinator, according to the experts, sex, marital status and number of children in the family, as well as confession or atheism coordinator and length of experience in a management position. Among the personal characteristics of respondents queued optimism, extroversion, self-confidence, self-control, emotional stability, empathy, flexibility, activity and responsibility.

A survey of the Institute for Criminology and Social Prevention implemented in the municipalities and counties in 2009 showed that more than $3 / 4$ of the respondents were in their functions prevention coordinator officially designated, most commonly Council resolution or even the city council. This appointment was anchored, and their function is reasonable to assume that in this way the representatives of municipalities showed their commitment to systematically deal with the prevention and longer term. Only a fifth of respondents coordinator (mainly from the cities to do preventive work involved for many years ) was in its functions taken on new posts and only less than $13 \%$ underwent the procedure of bankruptcy or any other form of tender. 
The work is undoubtedly Manager depends, inter alia, from the fact that the proportion of their working time can devote to prevention, not all managers can devote prevention program full time equivalents. In the abovementioned research, on average, managers estimated that dealing with crime prevention in $43 \%$ of the time.

The survey found that only rarely (in $14.3 \%$ of cases) is the activity coordinator of preventive activities only job description of the respondents. These workers operate in larger cities, which also have long experience in preventive work.

\subsubsection{Second phase middle - analysis, which should be implemented to prevent}

\section{Legal framework of preventive activities}

Večerka in his work (1997) points out that a good preventive work communities must be based on appropriate use of the legal system and the preventive potential of institutions, which may in a particular territorial area or region on the basis of existing legislation in the field of crime prevention work. This is especially the Police of the Czech Republic, whose main responsibilities under the Act No. 283/1991 Coll., On the Police of the Czech Republic, as amended, and territorial public authorities such as regional offices and various specialized bodies of local government, such as the Office work of the Czech Republic, the district social security, etc. the important role played by interest groups of citizens who can primarily prosocial act on its members, on the basis of existing legislation may be liable for those citizens who have committed any anti-social behavior, they have a real opportunity to positively influence their behavior and ultimately provide synergy administrations, courts and other public authorities in the exercise of their powers under the provisions of relevant legislation. Crime prevention at the local level, should primarily focus on public authorities such as municipal (city) police, which is established based on the Act No. 553/1991 Coll., The municipal police, as amended, the design of the advisory bodies local (municipal) councils and committees of the Council, a number of preventive measures in community exercises its delegated authority, to the extent determined by special laws ${ }^{9}$. Is governed by the laws and other generally binding regulations within their boundaries and also government resolutions and directives of the central government authorities.

\footnotetext{
${ }^{9}$ Delegated Powers of local government means that the content of the power of government is in a certain range of the delegate (delegated) to local governments. Delegated Powers circuit is therefore a matter of exercising the municipal authorities of the State, not on its own behalf, for the quality of the performance of the scope of responsibility of the state to the public that it has entrusted to the municipal authorities. It is a consequence of the Czech Republic applied the principle of a mixed model of public administration, which aims to bring government to the citizens. A somewhat different conception of the exercise of state administration can register in the Slovak Republic. "The state is the sum of the political institutions through which power is distributed in the coexistence of people. In the state include the Parliament, Government, Government and its agencies, local government, police, courts, etc." (Almášiová, 2012, p. 99). "The local government usually conducts its scope within the existing administrative-territorial division of the country. Currently, the only body of government with general competence is the district office. It is a local government authority in sections general internal administration of trade, civil protection and management in crisis situations outside the period of war and state of emergency" (Gejdošová, 2012, p. 173).
} 


\section{Summary of socio-demographic aspects}

The second phase of the process of systematic preventive work (and thus the protection of citizens against crime) can generally be regarded as a preparatory phase, which can be divided into two major areas. The first deals with work related to mapping problems of social pathology in a place where you have to implement preventive programs (analytical work ), the second part is focused on activities critically evaluating the current activities in the field of crime prevention including determinant of preventive work in the area (Večerka, 1997). The analytical phase of the Commission on Crime Prevention at the local level should begin a detailed description of the terrain in which to carry out planned preventative activities. It is a summary of the basic characteristics of the site in terms of socio-demographic and economic, i.e. primarily:

- Population (total and by individual neighborhoods),

- composition of the population by age and sex,

- the proportion of economically active people and addicts,

- occupational and educational structure of the population,

- national and ethnic composition,

- other local specifics in the composition of the population (Večerka, 1997).

The analysis should also affect such factors as the predominant type of buildings in the village, the rate of migration of the population, the number and type of jobs, an analysis of the causes of unemployment and its structure, development index of unemployment, but also non-economic variables, such as marriage, divorce and abortion. Inalienable has institutional analysis, this is a summary description of the amenities in the area, in particular the educational facilities, educational facilities, social services in the area of cultural and entertainment venues, and sports equipment. The aim of this activity is to clarify and streamline the basic givens locations that significantly determine the possible preventive procedures (Večerka, 1997).

Analysis of the initial pro-preventive social climate in Večerka in his work (1997) highlights, or analysis of socio-demographic characteristics of the sites can not, of course, reveal subtle patterns of social functioning mechanisms in the village. Similarly, it is not possible forensic analysis, which will be briefly discussed in the next sub-section, to clarify the location of people's social situation at the site in terms of their possible efforts to purposefully prevent emerging difficulties. The most important findings can be considered as citizens' views on the security situation in the village, their level of fear of crime, satisfaction with work safety authorities, etc. However, it is important to realize that even a high degree of sense of threat and considerable effort best to secure itself against criminal attacks may not bring people to the knowledge of the importance of preventive work. The person or body responsible for the creation of a system of prevention in the community should know the atmosphere prevailing opinion in respect of preparation of preventive activities. In smaller towns it is possible to rely on continuous monitoring of public opinion, in larger cities it is possible to use a smaller probe poll on whether 
prevention of yes or no and what direction focus. Many larger cities also lets agencies develop a sociological analysis of the security situation, which respond to the current status in the incidence of social pathology. Preparation of crime prevention at the local level can also be based on the results of a sociological survey focused on the perception of the safety of the citizens.

\section{Forensic analysis of sites}

Another important step in the preparation of crime prevention at the local level is a criminological analysis of the site, which aims to clarify where, when and what crime (or social pathology) is committed in the village and what are the characteristics of offenders (or holders of socio-pathological phenomena), or what conditions the occurrence of a certain type of criminal activity or socially pathological behavior depending on certain specific conditions that are present on the site. In effect, this means clarifying the determinants of antisocial behavior in terms of the type of offenders, victims, or other characteristics of the spatial context of social, economic, possibly environmental in nature (Večerka, 1997).

Important information in this area can provide us with both the city police and the Police of the Czech Republic, thanks to which we can determine the frequency of the most serious crimes in the area, what their character and composition of offenders.

Creating a list of real resources that are available in the implementation of prevention activities A very important part of the analysis of material determinant of location is to determine what resources a community prevention activities available. This inventory must be carried out systematically in order not omitted any personal or material resources that can be of use preventive work. It is necessary to take stock of all the possible subjects of preventive action that are under consideration, including their current factual possibilities, and interest to cooperate in prevention programs at the local level. The task of the committee members, crime prevention, as representatives of various ministries and agencies, the law should be to provide full information on the area. An important role in this phase plays undoubtedly coordinator (manager) crime prevention at the local level, which should have an idea of the possible deficiencies of personnel or material nature with respect to the issue of municipalities in crime and social pathologies (Večerka, 1997).

\subsubsection{The third phase - the creation of individual preventive programs and approval.}

Based on the information collected in the second phase it is necessary to proceed to decision problems in the village are treated as a priority and the solution of which the municipality has currently sufficient funds. It is necessary to emphasize that the individual preventive programs were complementary and that formed the core of the 
emerging comprehensive prevention program village. This means that the formation of the program must be based on specific ideas about what the community wants in a certain timeframe to achieve and how it intends to mobilize human, material and financial resources, which has provided to do so. Equally important is the creation of a specific prevention program at the local level balance sheet over who will be the subject or bearer of preventive action, as even the best preventive program proves to be as wrong, if not properly and responsibly sure who it will actually take place. Intensity targets specific preventive program should be consistently aligned with the skills, experience and professional knowledge of those individuals who will ensure the program. Finally, it must be clear who is going for the implementation of specific prevention program responsible, who will manage the entire program and which has competence in this direction. Well based preventive program is not without sufficiently precise description and specification means and methods that will be used to carry out the intent. An essential part of proper implementation of specific prevention program is of sufficient financial coverage, which should be carried out from three basic sources, namely from the state budget, sponsors and the community. Project specific program should be allocated to the individual if possible controllable phases in the control of the project plays a key role in crime prevention managers, who checks in cooperation with the economic department of the municipality (Večerka, 1997).

Assessment of specific prevention programs should be in the opinion Večerka (1997) form the opposition procedure, coordinator of prevention activities should be responsible for ensuring that each project has merits discussion in the Commission on crime prevention at the local level and then at least two opponents. In the context of expert opinions should in particular examine whether partial preventive program compatible with other programs that are currently being implemented, whether directed to the achievement of the agreed goals of preventive community and whether it is secured for all sites.

After discussion of a comprehensive prevention program in the Commission on Crime Prevention considers it useful to discuss the management structures of community planning in the village. Subsequently, the program should be crime prevention discussed and approved by the council and municipal council, if the municipality will require the implementation of its contribution from the state budget, it must submit for consideration republican Crime Prevention Committee and the Commission for the selection of projects for urban crime prevention program, which is an advisory body.

\subsubsection{The fourth phase - the evaluation of the success of prevention programs}

During each of the prevention program should be monitored and crime prevention manager at the regular meetings of the Commission on Crime Prevention at the local level. Final evaluation of the success or failure of a particular prevention program should be implemented on the basis of predetermined indicators. Our experience shows that the creation of a comprehensive Cooperation Programme and prevention of crime and 
social pathology is from the creators of the definition of indicators neglected, which complains and in many cases even impossible to evaluate the program.

Evaluation of preventive programs or activities to date (not only in our country) pays relatively little attention and disorganized. It is certainly worth pondering why this is; after all, the attributes of human creative endeavors include general Fundamental need to ask about the meaning of effort, the result of commitment. The general answer to this question is discussed in our area is the very fact of great difficulty adequate and objective evaluation. There is no general measure of success of a prefabricated preventive work. It is always necessary over and over again depending on the type and nature of the problem and influenced by means of the modification. In any particular project we are faced with the need to re-formulate realistic goals and time horizon of a specific program of action here and now. It is important to clarify what can be considered a success of the project and then to the stage, in relation to the nature of the modified entities or situations. Paradoxically, sometimes seemingly slight shift in the attitudes and behavior of individuals affected by the so-called tertiary prevention can actually be far more successful than bombastically proclaimed successes circuit of events that can be incurred when certain resources or activities regarded as almost self-evident. It should be also taken into account that the objective reasons, not all of the effects of certain preventive actions are immediate and measurable results that preventive activities often have a mechanical linear character. In any particular project we are faced with the need to re-formulate realistic goals and time horizon of a particular action. Similarly, we are not always able to do their considerations include all the possible consequences of a bequeathed state. From what has been stated above, does not mean that we should give up on evaluation as a process, which is what most brings to mind the reasons for our preventive options. Evaluation is not a mechanical process, but rather a factual analysis of the relevant documents. It is necessary to show what you can prove and what to do with regard to the project objective sense. Can not settle for saying that something works (or does not) in the expected direction of, but need to constantly question the causes and conditions of the functioning of the preventive mechanism. Scoring is ideally, focused process of balance sheet over the existing activities with an intention to learn in the future. This process is not - as is unfortunately often the case - in mindless scoring for evaluation (Večerka, 2001).

\section{Conclusion}

At the end of the last century, the Czech Republic, in accordance with good practice criminological advanced democracies, pushed the idea that increasing crime can not in any case face a mere increase in repressive means. It was recognized that the mere threat of a tightening of criminal repression nor related augmentation of numbers in the police, the number of prosecutors or judges or prison capacity expansion, never led to the removal and even often do not reduce crime. In addition, the highly repressive means a 
very challenging economic and burden the budget of each state. The mere repression addition aim in particular does not meet expectations because the conscious personality characteristics criminally prepared and dedicated people are in a crushing number of cases such that will not allow the idea that they could be in the commission of the offense detected, located and subsequently affected. Increased criminal repression intimidates particularly upstanding individuals who inappropriately involve their fear of punishment and believe that suffer from the same fears and criminal population.

Crime prevention in varying degrees match whole society, but primarily public authorities, both at central and at regional and local level. Without a multidisciplinary approach, the crime can be controlled or reduced only with difficulties, prevention activities must be directly aimed at subjects of prevention at the local level and reflect local characteristics and the situation.

\section{References}

Presented text is an original from the author (unless stated otherwise) and it can elaborate on topics or theses already included in previously published works of the author.

Almášiová, A. (2012). Sociológia [Sociology]. Ružomberok: Verbum.

Crime Prevention. (2008). [online]. Accessed 21 March 2013. Retrieved from: http:// aplikace.mvcr.cz/archiv2008/prevence/system/pojmy/1.1.htm.

Crime Prevention Strategy in the Czech Republic for 2012-2015. (2011). Prague: Ministry of the Interior.

Gejdošová, Z. (2012). Sociálne zabezpečenie v systéme verejnej správy na Slovensku [Social security system of public administration in Slovakia]. Ružomberok: Verbum Publishing - Catholic University in Ruzomberok.

Lejinš, P. P. (1967). The Field of Prevention. In: W. E. Amos, \& Ch. E. Welford (Eds.), Deliquency Prevention (pp. 1-21). NY: Engelwood Cliffs.

Miovský, M. (2010). Historie a současné pojetí primární prevence rizikového chování $\checkmark$ české republice [History and current concept of primary prevention of risk behavior in the Czech Republic]. In: M. Miovský, L. Skácelová, J. Zapletalová, \& P. Novák (Eds.), Primární prevence rizikového chování ve školství [Primary prevention of risk behavior in schools] (pp. 13-28). Prague: Association SCAN, Charles University in Prague \& Toga. 
Pilát, M. (2012). Komplexní součinnostní program prevence kriminality a sociální patologie na místní úrovni [Liaison comprehensive program of prevention of crime and social pathology at the local level]. In: Z. Gejdošová, O. Okálová, \& A. Almášiová (Eds.), Prevencia v praxi (protidrogová politika a prevenci vo verejnej správe). Zborník príspevkov z medzinárodnej vedeckej konferencie [Prevention in Practice (drug policy and prevention in public administration). Proceedings of contributions from international scientific conferences] (pp. 66-72). Ružomberok: Verbum Publishing - Catholic University Ružomberk.

Pilát, M. (2013). The Program of Crime Prevention and Social Pathology in the Czech Republic. Ružomberok: Verbum Publishing - Catholic University in Ruzomberok.

Štefunková, M. (2012). Východiska a teoretický rámec prevence kriminality [Background and theoretical framework of crime prevention]. In: M. Štefunková, \& J. Šejvl (Eds.), Základy prevence kriminality pro pedagogické pracovníky [Principles of crime prevention for teachers] (pp. 11-36). Prague: Toggi.

Tvorba a realizace projektů prevence kriminality. Development and implementation of crime prevention projects. (2007). E. Havrdová (Ed.), Prague: Center for Public Policy.

Večerka, K. et al. (1997). Prevence kriminality $v$ teorii a praxi [Crime prevention in theory and practice]. Prague: Ministry of the Interior.

Večerka, K. (2001). Úspěšnost preventivní práce (zamyšlení nad problematikou vyhodnocováni preventivních programů) [The success of preventive work (Reflections on the problems of evaluating prevention programs)]. Prague: Institute for Criminology and Social Prevention.

\section{Author}

PaedDr. Miroslav Pilát, Ph.D.

Faculty of Public Policies, Silesian University in Opava Institute of Public Administration and Regional Policy Bezručovo nám. 885/14, 74601 Opava, The Czech Republic miroslav.pilat@fvp.slu.cz 